\title{
The impact of externalized migration governance on Turkey: technocratic migration governance and the production of differentiated legal status
}

\author{
Ayşen Üstübicio
}

Correspondence: austubici@ku.edu.tr Department of International Relations, Koç University, Rumelifeneri Yolu, 34450 Sarıyer Istanbul, Turkey

\begin{abstract}
The article highlights international dimensions of the emergence and transformation of migration policies in Turkey from the early 2000s onwards, including the context of the Syrian displacement, which made Turkey the top refugee hosting country in the world. While the transformation of migration governance in Turkey has widely been discussed, the effects of externalization on Turkey have remained focused on foreign policy and Turkey-EU relations. Only recently has the research explored the socio-legal implications of migration governance in terms of the emergence of categorizations leading to differentiated inclusion of migrant groups. The article establishes the historical and conceptual link between technocratic responses to externalization dynamics and the emergence of differentiated legal status. The article argues that measures of externalization brought a technocratic approach to migration governance. As a result, the complex, controversial aspects of the externalization process, such as the production of differentiated legal statuses amongst migrant communities with protection needs, have so far been overshadowed.

Keywords: Externalization of EU migration policies, Turkey-EU relations, Differentiated legal status, Syrian refugees in Turkey, Technocratic framing of migration governance
\end{abstract}

\section{Introduction}

European Union (EU) external governance is generally defined as the expansion of EU rules beyond EU borders (Lavenex \& Schimmelfennig, 2009; Qadim, 2014, p. 244). Externalization in the context of migration governance has been widely used to refer to the transfer of border management to third countries and the redefinition of migration management beyond the territorial borders of destination states. Turkey, treated by the EU almost simultaneously as a candidate country and a third country, has been directly affected by EU externalization. This article reframes the impact of externalization and discusses how the external and technical character of the EU accession process in Turkey has played a role in the legal construction of migrant (il)legality in a multi-layered and differentiated way.

(c) The Author(s). 2019 Open Access This article is distributed under the terms of the Creative Commons Attribution 4.0 International License (http://creativecommons.org/licenses/by/4.0/), which permits unrestricted use, distribution, and reproduction in any medium, provided you give appropriate credit to the original author(s) and the source, provide a link to the Creative Commons license, and indicate if changes were made. 
Turkey constitutes an interesting case for discussing and potentially theorizing the legal-infrastructural and socio-legal implications of externalization practices. The legal infrastructure in this article refers to changes in the legal framework regarding the governance of mobility as well as institutional arrangements that underpin changes in law and practices. Socio-legal implications here refer to outcomes of policies for the social and political integration of migrants with various legal statuses.

Acknowledging that Turkey is not a passive recipient of EU externalization when it comes to negotiating with the EU over migration related topics (Ataç et al., 2017) (see also İçduygu \& Üstübici, 2014; Karadağ, 2019, this issue), the article makes two interrelated arguments on the socio-legal effects of externalization. First, externalization measures have led to the technocratic, rather apoliticized framing of migration governance in Turkey. The technocratic approach to migration governance continued, even under conditions in which one would have assumed politicization to have been inevitable, such as the arrival of large numbers of displaced refugees over a short time period. ${ }^{1}$ Second, the technocratic approach to migration governance has overshadowed the complex, controversial aspects of externalization such as the production of differentiated legal statuses amongst migrant communities with protection needs.

The analytical connection between the technocratic approach to migration and the production of differentiated legal status is established through an inter-connected reading of recent literature on the EU impact on Turkey's migration governance from early 1990s until the present challenge of refugee arrivals from Syria and on the conceptual framing of externalization practices from critical security studies. Hence, the discussion in the article draws on emerging literatures on the external dimension of EU migration and border policies (Boswell, 2003; Frelick, Kysel, \& Podkul, 2016; Genç, Heck, \& Hess, 2019; Lavenex \& Uçarer, 2004; Wunderlich, 2013), global migration management (Geiger \& Pécoud, 2010), critical border studies (Bigo, 2014; Pallister-Wilkins, 2015; Tsianos \& Karakayali, 2010), and the legal production of migrant illegality (De Genova, 2004) as well as the recent scholarship on differentiated inclusion in Turkey (Baban, Ilcan, \& Rygiel, 2017; Genç et al., 2019; Sözer, 2019).

The paper historicises the emergence of Turkey as a geography of 'transit', and later as a 'safe haven', looking at the impact of EU externalization on the political and institutional context of migration governance. The methodology encompasses a multimethods approach that not only includes stakeholder interviews but also observations in policy meetings on migration governance as well as a critical and close reading of secondary literature and policies. ${ }^{2}$ Policy developments in migration governance since the early 1990s, but especially since 2003 when Turkey's harmonization with the EU acquis gained momentum, provide the basis for the analysis.

The article first evaluates the literature on externalization practices, where I trace the institutional implications of border externalization practices at the conceptual level and engage with the recent literature on Turkey. The following parts of the article present a

\footnotetext{
${ }^{1}$ The term politicization refers to the fact that immigration related issues have generally been part of high politics. What I later refer to as apoliticization refers to the fact that political parties in Turkey did not necessarily have an explicit stance on immigration issues until the June 2015 elections.

${ }^{2}$ The empirical discussion is based on the analysis of policy documents produced by the EU and Turkish government. In order to understand the functioning of laws, I conducted over 25 expert interviews from 16 institutions in Turkey, including state departments, international organisations and civil society organisations (CSOs) throughout 2012 and 2013, as part of a larger PhD research.
} 
chronological and analytical overview of migration governance in Turkey since the late 1980s in terms of the emergence of transit spaces in the context of EU border policies. The focus on the post-2008 period reveals how the external and technocratic character of migration law making in Turkey and the production of migrant illegality were reconstructed through immigration law. The last part of the article highlights the continuation of the impacts of externalization in interaction with other factors on the governance of mass refugee movements, using the example of the Turkey-EU statement of March 2016 as the latest obvious instrument of externalization.

\section{Border externalization and its socio-legal implications}

As EU interest in controlling irregular migration and asylum flows has grown, the border areas neighbouring Europe have been shaped through various forms of border closure policies. In the late 1990s and 2000s, the diffusion of norms, laws and institutions resulted in the tightening of EU border policies. As Huysmans (2006) noted regarding the securitization of migration in the EU context, the elimination of internal borders was conditioned on the strengthening of external borders. Consequently, border closures at the external borders of the EU were coupled by conditionality requiring neighbouring countries to play an active part in 'combating' irregular migratory flows, within the logic of externalized migration control. In this context, border externalization commonly refers to 'a series of processes of territorial and administrative expansion of a given state's migration and border policy to third countries' (Casas-Cortes, Cobarrubias, \& Pickles, 2016, p. 231).

This preoccupation with securing EU borders through externalizing border controls has had diverse outcomes. As the measures making mobility costlier and riskier for migrants were strengthened, public attention turned to 'border spectacles' as the media depicted large groups in crowded boats, people climbing wired fences and bodies washing onto shore (De Genova, 2015). Research on the immediate effects of border closures reveals that rather than fortresses, border zones have become gates filtering those who are allowed to enter and then who need to be protected and those to be detained and returned (İşleyen, 2018b; Pallister-Wilkins, 2015; Qadim, 2014). Deterrence measures such as removal, detention, and deportation as immediate effects of externalization have been widely criticized for their life threatening consequences. This is the reason why most control and containment measures involve life-saving humanitarian endeavours claiming 'to protect migrants from the dangers of the journey' (Frelick et al., 2016, p. 193). In this context, along with control and filtering, border zones are also sites of humanitarian intervention and care as widely theorized through an extension of Foucauldian lens of bio-politics from a geographical perspective (İşleyen, 2018b; Pallister-Wilkins, 2015). In these border zones, gatekeepers such as border guards see themselves as technical managers of flows, judging the intentions of individuals (Bigo, 2014, p. 215), and at the same time as humanitarian workers (İşleyen, 2018a; Pallister-Wilkins, 2015).

These studies show how rescue operations and humanitarianism serve to justify the technologies of border enforcement. Not only deterrence, but also 'humanitarianism moves beyond conventional territorial boundaries [.....] to neighbouring countries of transit and origin' (İsleyen, 2018b, p. 853). Yet, few studies discuss how this interplay between humanitarian intervention and control mechanisms has been translated 
beyond the border as a socio-legal effect of externalization, whereby not only border guards but various actors of migration governance have become engaged in filtering migrants and asylum seekers in need of care.

Along with direct action in terms of non-entry policies, 'indirect actions, such as the provision of support for or assistance to security or migration management practices in and by third countries' have become widespread. As it required active involvement by these third countries, such practices are mostly framed as 'an exercise in capacity building for countries of origin, countries of first arrival, and transit countries' (Frelick et al., 2016, pp. 193, 196). Disguised under the technocratic language of capacity building, another priority area for EU migration management has been to invest in the legal infrastructure of third countries to ensure that these countries embrace an adequate legal framework to provide protection for migrants and refugees (Geiger \& Pécoud, 2010, p. 7). Hence, spaces of transit have not only become gates to filter who may enter the EU but also sites of humanitarian intervention where unwanted migrants can be returned. EU externalization practices thereby function as a means for third countries to internalize norms of migration governance (Brouillette, 2018, p. 17).

The external dimensions of EU border policies have had a direct influence on the securitization of irregular migration and technocratic functioning of migration governance outside European borders. As discussed by Geiger and Pécoud (2010, p. 9), the externalization of migration management is performative in the sense that immigration restrictions produce migrant illegality and construct migrants as 'illegal subjects', contributing to their subordinate inclusion as a docile labour force in the domestic labour market (De Genova, 2004; Garcés-Mascareñas, 2012). As put by Menjivar, the construction of immigrant illegality, 'is no longer confined to the territorial borders of the receiving country; it is a process that starts before immigrants arrive at the physical border, in transit areas and, in some cases, even at the point of departure' (Menjívar, 2014, p. 363). Meanwhile, more discussion is needed on what kind of legal subjectivities are produced in countries affected by externalized and technocratic approaches to migration management and how these processes are informed by the logic of border externalization based on control and humanitarian intervention. At this point, Turkey is a case in point to reveal the technocratic character of emerging forms of governance and their socio-legal implications.

The transformation of migration governance in Turkey has been widely discussed, initially in relation to EU conditionality (İçduygu, 2007; Lavenex \& Uçarer, 2004; Ozcurumez \& Şenses, 2011; Tolay, 2012). While the literature on Turkey-EU relations and foreign policy focus on the mechanisms of policy transfers and explore the bargaining power exercised by third countries such as Turkey (Aras \& Mencütek, 2018; İçduygu \& Üstübici, 2014), they have put less emphasis on the socio-legal implications. Since the arrival of Syrian refugees, migration scholars working on the case of Turkey have emphasized the differentiated inclusion in relation to various groups of migrants and refugees (Baban et al., 2017; Genç et al., 2019). Others problematized differential treatment among Syrians either based on ethnicity (Korkut, 2016) or on several criteria of vulnerability (Sözer, 2019). As Sözer (2019) discusses, the categories differentiating among Syrian refugees has been re-defined at the stage of implementation. Both Baban et al. (2017) and Korkut (2016) suggest that Turkey's reception policy towards Syrian refugees has been geared towards a humanitarian approach, not towards a long term integration. 
These recent studies on Turkey have evaluated the situation since 2011 from a sociolegal perspective but without necessarily emphasizing the continuation of earlier forms of migration governance in the context of the external dimension of EU border and migration policies. There is need to underscore that these effects are not new and reflect implicit ways of differentiation from earlier periods (see Biehl, 2015; Üstübici, 2018). Among the recent literature, Genç et al. (2019, p. 500) emphasizes the continuation of the governance regime and rightly point to the new trend regarding the emergence of a 'multilayered migration regime' and draw attention to 'how the EU-Turkey deal disenfranchises people' in need of protection. However their analysis, albeit valuable, does not sufficiently discuss mechanisms of externalization and responses to it (see Stock, Üstübici, Schultz, this issue). In relation to these emerging and fruitful literatures, the article invites us to read the recent developments in Turkey as the continuation of a historically technocratic approach to migration governance despite recent politicization and, at the same time as an extension of control and humanitarian dynamics widely discussed in the context of border externalization.

\section{Pre-2008: emergence of 'technical commitment' to govern migration}

Over the last few decades, Turkey has faced various mixed migratory flows, which have created a complex migration system involving irregular labour migrants, transit migrants, asylum seekers, refugees and regular migrants. In contrast to immigration and asylum policies in Europe, which are becoming increasingly selective and restrictive as discussed above, Turkey's related policies and practices only partially reveal similar trends. On the one hand, Turkey still applies the geographical limitation to the 1951 Convention Relating to the Status of Refugees and so does not offer the right of stay to refugees originating from non-European countries. Thus, the current asylum regime has pushed recognized refugees to settle in third countries through a long and bureaucratic process, available only to a small minority of refugees in Turkey (Yıldız \& Sert, 2017). On the other hand, Turkey also employs liberal visa policies to nationals of third countries who are subject to rather strict Schengen visa regulations. As a result, the country's borders are permeable to human mobility while the impact of externalization continues to shape the priorities of migration and border policies.

Turkey has been subject to externalization of migration management since the early 1990s (Fine, 2018; Oelgemöller, 2011). Drawing on communications between the Intergovernmental Consultations on Migration, Asylum and Refugees, the United Nations High Commissioner for Refugees (UNHCR) and Turkey, Oelgemöller (2011, pp. 414415) suggests that Turkey was the first country to be identified as a transit space, as early as 1987, for its role as a first asylum country for refugees fleeing conflicts in the region, such as the Iranian Revolution, the Iran-Iraq War and the Gulf Crisis. Meanwhile, in Turkey, the 1980s was a period of government neglect towards the phenomenon of their own nationals, and increasingly third-country nationals, crossing into the EU. Official negligence continued until the mid-1990s when Turkey was identified as a transit zone by the EU. Under external pressure by the EU, but also equipped with technical and administrative support, Turkey became responsible for policing unauthorized migration flows, although the framework of legal changes was rudimentary and contested at times. 
Throughout the twentieth century, Turkey was a land of immigration for Muslim and Turkic groups from the wider region, but these arriving groups were perceived as natural citizens rather than foreigners. According to the 1934 Settlement Law, immigrants were defined as those of Turkish descent and culture who came to settle in Turkey. ${ }^{3}$ Only in the early 1990s, mass inflows during the Gulf Crisis and at the peak of the Kurdish armed conflict in the Eastern part of the country urged authorities to introduce regulations on the treatment of large groups of displaced people arriving in Turkey. According to the 1994 Regulation, the Ministry of the Interior (MoI) became the final decision-making body for refugee status determination (RSD), in collaboration with the UNHCR. ${ }^{5}$ While the 1994 Regulation signals the transition to international norms (İçduygu \& Bayraktar Aksel, 2012, p. 40), it did not provide a clear procedure for international protection applications until the amending document in 2006 (Soykan, 2017, p. 54). Indeed, the post-1994 period is characterised by rights violations by Turkey, especially the right to non-refoulement and an increasing number of cases against Turkey at the level of the European Court of Human Rights (ECtHR) (Kirişci, 2012, pp. 67-68). Many people in need of international protection were deported before gaining proper access to the asylum process. Although the 1994 Regulation is a milestone for migration governance in Turkey, due to problems in capacity and implementation, it failed to filter between asylum seekers and other categories of migrants.

Putting 1994 Regulation aside as a securitized response to regional conflict, Turkey's transition from having no immigration policy to the adoption of externalization measures through the EU accession process has been gradual. Turkey's long-standing candidate-member status and its commitment to adopt the EU acquis have been major anchors for Turkey's cooperation with the EU on the issue of migration and asylum. Immigration legislation and institutionalisation have been mainly discussed in public and policy circles within the context of technicalities of the EU accession process (İçduygu, 2007; Ozcurumez \& Şenses, 2011; Özgür \& Özer, 2010). As discussed below, this process can also be read as a case of institutionalization of the legal production of migrant illegality through externalization.

After the initial phase leading towards the adoption of international norms on asylum, the signing of the Accession Partnership Agreement with the EU in 2001 provided the impetus for legislative and institutional changes in the field of asylum and migration management in Turkey. The period between 2003 and 2008

\footnotetext{
${ }^{3}$ The policies shaped around this logic reveal continuity in the sense that even today, some groups or individuals can more easily access legal residence - although the acquisition of citizenship has become more strenuous - on the basis that they are of Turkic descent, mostly defined as Turkish speaking Sunni Muslims (Danış \& Parla, 2009).

${ }^{4}$ The legislation commonly referred to as the 1994 Regulation is officially entitled 'The Regulation on the Procedures and the Principles Related to Mass Influx and the Foreigners Arriving in Turkey either as Individuals or in Groups Wishing to Seek Asylum either from Turkey or Requesting Residence Permits with the Intention of Seeking Asylum from a Third Country'. The main drive for the introduction of the regulation was the government's concerns over border security rather than prospective EU membershiprelated factors.

${ }^{5}$ As a result of the 1994 Regulation and its Implementation Directive enacted in 2006, both the MoI and UNHCR process the applications of asylum seekers. However, Kirişci notes that, in time, the MoI came to rely more on decisions by the UNHCR (Kirișci, 2012, p. 69).
} 
was characterised by legal activism in the context of Europeanization as well as increasing civil society awareness. The adoption of the Law on Work Permits of Foreigners, changes in the law regulating the acquisition of citizenship through marriage and the harsher sentences introduced for human trafficking and smuggling in 2003 were among the important and unprecedented legal changes related to international migration in Turkey in the post-2000 period. $^{6}$

At the level of implementation, however, enforcers - primarily in the police department - had little awareness about the legal framework and a wide space for discretionary power. Vague terminology in the law, such as 'Turkish traditions', 'political requirements', and 'violating peace and security', as variously interpreted by decision makers, served as grounds for detention and deportation and led to various forms of human rights violations (Dardağan Kibar, 2013; HCA, 2007; Yllmaz, 2012). The nascent asylum-related civil society played an important role in exposing arbitrary implementations of the policy in the absence of adequate legislation. ${ }^{7}$ Such insights revealed implementers were the ones to decide on individuals' legal status. They were not only implementing laws but also acting as intelligence officials to decide who was allowed and who was not (Bigo, 2014, p. 215). An experienced official from National Security confirmed that in the absence of clear guidelines, they followed their own routines, 'we are provided a wide discretionary power if we think it is appropriate, we can permit people to stay for another 6 months'. ${ }^{8}$ Another one added that the control aspect may be undermined in some cases, as the implementers may not directly feel responsible for migrants working in the informal sector, saying that 'the Ministry of Labour has inspectors for it.. ${ }^{9}$ In other words, differentiated inclusion was less about legal status and more about implementation.

Several of the measures adopted in the post-2003 period continued to rely on discretion and underpinned the technocratic character. In this period, administrative, financial and technical support by the EU and its member states played an important role in making asylum and migration a subject of governance (Özgür \& Özer, 2010, pp. 138-139). Officially starting with the 2003 Strategy Paper for the Protection of External Borders, border management, migration management and asylum issues have been on the table as part of EU membership talks. The National Action Plan for Asylum and Migration, adopted in March 2005, was a product of a twinning project with Denmark and the UK conducted between March 2004 and March 2005. The National Action Plan envisaged legislative and institutional changes to harmonise Turkey's asylum and migration legislation with that of the EU acquis. The framework of the Action Plan on Integrated Border Management, adopted in 2007, was initiated alongside another twinning project in collaboration with the UK and France. The EU's conditionality, and financial and administrative support by the EU and member states, clearly marked the novel, external and technical character of the emergence of migration governance in Turkey (Üstübici, 2018, p. 59).

\footnotetext{
${ }^{6}$ For a detailed overview of EU-led changes in post-2003 period, see İçduygu and Aksel (2012).

${ }^{7}$ Author interview with a CSO representative working on refugee rights, Istanbul, 26.11.2013.

${ }^{8}$ Author notes from unrecorded interviews at the General Directorate of Security, Ankara, December 2012.

${ }^{9}$ İbid.
} 
As an important tool of EU border externalization, after years of negotiations, Turkey signed a Readmission Agreement (RA) with the EU in December 2013. ${ }^{10}$ The readmission concerns nationals of EU Member States and Turkey, plus third-country nationals and stateless persons who 'entered into, or stayed on, the territory of either sides directly arriving from the territory of the other side' (EC, 2013). Turkey signed the RA in 2013, in exchange for the initiation of EU-Turkey visa liberalisation dialogue. In other words, Turkish nationals' potential visa-free travel to European countries depends on Turkey's efforts to stop irregular migration into the EU. Signalling the continuation of the technocratic logic of earlier forms of externalization, the RA was represented in the media as a technical commitment by Turkey to open 'the borders of Europe' for its own nationals. There was little discussion and almost no official statements on what the RA entailed in terms of cooperation between the EU and Turkey on matters related to irregular migration, let alone the protection of migrants' rights (Kılıç, 2014, p. 429). These instances of cooperation contributed to the institutionalization of the legal framework and practices of migration management but also to the normalization of its apolitical, technical character.

Not only EU institutions but also intergovernmental organizations have become active in the transfer of externalization practices (Geiger \& Pécoud, 2010, pp. 3-4). International organizations have played an important role in bringing Turkey's immigration and asylum policies in line with the requirements of EU migration policies and contributed to technocratization of migration governance. In this context, emerging activities by the UNHCR and the International Organization for Migration (IOM) enhanced the external character of the governance of migration and asylum issues in Turkey. A bilateral agreement was signed in 1995 and Turkey became a full member of the IOM in 2004, revealing Turkey's commitment to an EU model of migration management (Fine, 2018). In close cooperation with particular EU states, the UNHCR and the IOM, the Migration and Asylum Bureau and the Bureau for Border Management were established in October 2008 under the Ministry of Interior. These two organisations, namely the UNHCR and the IOM have provided administrative support for the activities of newly staffed bureaus under the Ministry. The establishment of these two Bureaus is indicative of the institutionalization of the migration bureaucracy. The main mission of the Migration and Asylum Bureau was to draft the Law on Foreigners and International Protection (LFIP). The latter, I suggest, is a clear sign of the internalization of certain norms of migration governance and solidified the emergence of differentiated legal status.

\section{Internalization of external norms of governance: 2008-2014}

The LFIP came into force in April 2014, envisaging substantive legal and institutional changes that arguably brought about a new phase in the governance of immigration and asylum in Turkey. The process has led to the institutionalisation and emergence of a bureaucratic cadre focused on immigration in the post-2008 period. As the name suggests, the LFIP includes laws regarding foreigners and asylum, bringing together

\footnotetext{
${ }^{10}$ The readmission agreement between Greece and Turkey had already come into force in 2002. However, there have been severe problems of implementation, which were due to reluctance by Turkey to agree to readmit irregular migrants who had allegedly crossed into Greece through Turkey. Negotiations over an RA took several years, as Turkish officials had concerns that, without being a full EU member, the country would become a 'dumping ground' for irregular migrants apprehended in EU territories.
} 
formerly scattered pieces of legislation on the entry, stay and deportation of foreigners. For the first time, Turkey's asylum policy is codified as law, as opposed to secondary legislation that mainly referenced regulations from earlier periods. As a major institutional novelty, the law centralized policy making and implementation in the field of international migration and asylum under the Directorate General of Migration Management (DGMM). Before the LFIP, various state bodies were simultaneously responsible for policies concerning immigration. ${ }^{11}$ As envisaged by the law, the DGMM and its organisations that are institutionalised at the provincial level gradually took over responsibilities from the Turkish National Police.

The main motivations for the institutionalisation of immigration and asylum governance in the post-2008 period were the commitment to the adoption of the EU acquis, preventing additional decisions by the ECtHR against Turkey and growing international and domestic civil society activism leading to critical reports on rights violations (Kirişci, 2012, p. 77).

The LFIP came into force after a relatively open deliberation process with stakeholders yet without much public discussion on the subject (Kirişci, 2012; Üstübici, 2018, pp. 75-77). Along with the technical priorities of the EU accession process, officials interviewed from various state departments, such the Ministry of Foreign Affairs, Ministry of Interior, Ministry of Labour, widely referred to Turkey's 'own dynamics' mainly the growth in the Turkish economy since the economic crisis in 2001 - to justify the conviction that Turkey's need for these reforms had become widespread regardless of EU accession prospects. At the same time, there was little reaction among stakeholders in Turkey on how EU-inspired restrictions on the entry of foreigners would impact the different types of migrants within the ongoing, relatively lax mobility regime between Turkey and its neighbours in the East and South. In other words, there was little discussion on the unregistered foreign labour force, mostly coming from less wealthy countries in the wider region, which has predominantly been informally employed in small and medium sized workplaces in construction and related industries, as well as in sectors such as leather, textiles, agriculture, care and tourism (Toksöz, Erdoğdu, \& Kaşka, 2012, pp. 72-76).

Interestingly, there were few public debates and hardly any negative views on this emerging immigration policy realm during the preparation and legislation processes. Civil society actors who contributed to the policy making process acknowledged that opposition parties were also constructive as 'was the case with similar EU alignment measures.' ${ }^{12}$ As highlighted by a civil society representative, 'as the issue was not considered as political, the discussions were held in a technocratic way. ${ }^{13}$

The LFIP aims at providing a clear differentiation amongst asylum seekers, legal migrants and unauthorised migrants (Tolay, 2012) as an extension of ongoing practices of externalization along the EU-Turkey border. On the one hand, apprehensions, detentions and deportation continue to be the main pillars of migration control and the DGMM detention capacity has increased over the years (Grange \& Flynn, 2014). On the other hand, as direct response to ECtHR decisions against Turkey, the law ensures

\footnotetext{
${ }^{11}$ The most prominent of them are the Department of Foreigners, Border and Asylum under the Directorate of General Security of the Ministry of the Interior and the Deputy Directorate General for Migration, Asylum and Visa under the Ministry of Foreign Affairs.

${ }^{12}$ Author interview with a CSO representative working on refugee rights, Istanbul, 26.11.2013.

${ }^{13}$ Ibid.
} 
procedural guarantees, the right to appeal decisions on entry bans, detentions and deportations. The LFIP responds to critiques from different actors, through standardized treatment of foreigners and leaving less room for discretion in the hands of authorities, especially with respect to deportation and detention decisions (Dardağan Kibar, 2013).

Highlighting the novel aspect of the law, one official from the police department explained the aim of the law as follows: 'The food comes into the body, if it is good [legal] it is digested; if it is bad [illegal], it is thrown away'. ${ }^{14}$ While he implies a degree of absorption, reservations from earlier periods have been safeguarded (Ozcurumez \& Şenses, 2011). Provisions in the law ensure the principle of non-refoulement, access to asylum and enjoyment of fundamental rights by asylum seekers and refugees. However, the LFIP does not lift Turkey's geographical limitation on the Geneva Convention; only those from European countries can be admitted as refugees in Turkey. As codified in the LFIP, asylum seekers from non-European countries, if recognized, would become 'conditional refugees' and eventually be resettled to third countries. As the metaphor in the quote above suggests, the content of the law arguably aims to reinforce its filtering function between asylum seekers' legitimate right to stay, eventually to be re-settled, and the illegitimate presence of irregular migrants and fraudulent asylum applicants.

The legal framework coupled with implementation had already differentiated among groups seeking protection before the Syrian displacement escalated. As was clear from interviews with civil society representatives in 2012, because of the high number of applicants, applicants from Afghanistan and Iran could 'pre-register' and be sent to satellite cities. Their RSD process would only start in the following years. In other words, back in 2012 'an Iranian could only have UN registration date for 2014 and an Afghan for May $2015{ }^{\prime 15}$ In particular, asylum seekers from Afghanistan appeared to be at the bottom of the hierarchical functioning of international protection, as UNHCR later totally suspended their registration process, because they are considered to come from a safe country and hence were potentially subject to deportation. LFIP's measures and implementation at best provide a humanitarian basis for protection and were far from providing a long term solution. Interestingly, the arrival of Syrian refuges, initially welcomed to camps in cities bordering Syria, was not part of discussions concerning the enactment of the LFIP. Echoing the general lack of public and parliamentary discussions on the subject of immigration and asylum (Tolay, 2012), officials considered the flows from Syria to be temporary and hence refrained from reflecting on long term solutions.

\section{Externalization and the challenge of mass migration: 2014-onwards}

Since 2011, Turkey has faced mass flows of Syrians fleeing civil war, who were initially settled in camps in the South-East region bordering Syria and called 'guests'. The label 'guest', a non-existent category in international law, underscores the expectation of Turkish authorities that the conflict would end in the near future and Syrian refugees would return to Syria. Despite the dramatic increase in the number of non-camp refugees, there was no legal framework or publicly available policy document on how the 'guests' from Syria would be incorporated, except for circulars on access to free public

\footnotetext{
${ }^{14}$ Author notes from unrecorded interviews at the General Directorate of Security, Ankara, December 2012.

${ }^{15}$ Interview with a CSO representative working on refugee rights, Ankara, 18.12.2012.
} 
health services and education. In other words, the vague policy response to Syrian displacement was not necessarily EU-driven as in the post-2008 policy developments, not as securitized as in the case of 1994 regulation explained above.

Finally in October 2014, the Regulation on Temporary Protection (RTP) specified the terms of registration and stay in Turkey without determining the length of protection. ${ }^{16}$ In general terms, the LFIP had distinguished between legal migration, irregular migration, international protection and subsidiary protection. Although temporary protection as a legal status is not recognized in international law, Syrians under temporary protection are neither (conditional) refugees nor asylum seekers under the LFIP (Ineli-Ciger, 2015). The enactment of the RTP, based on Article 91 of the LFIP, gave rise to a new category and a new level of legal differentiation when compared to those entitled to international protection in terms of the level of access to rights and recognition. In the case of Syrian refugees, we see that their entitlement to temporary protection is legally constructed upon their overwhelming numbers, vulnerability and immediate need for protection, whereas all other categories of people claiming international protection in Turkey are required to prove their need for protection.

When compared to other categories of asylum seekers, Syrians under RTP have easier access to registration, services and aid than conditional refugees from non-European countries waiting to be re-settled, asylum seekers waiting for their status to be determined by the DGMM and the UNHCR, and asylum seekers not admitted to asylum procedures or the re-settlement scheme. Syrians under RTP initially entered Turkey through an open door policy and could choose their city of registration, whereas asylum seekers from other nationalities are required to reside in their designated 'satellite city' upon registration with authorities. Meanwhile, Syrians are largely excluded from RSD procedures to be re-settled in a third country. Plus, once they register in a province, their mobility within the country is also subject to restrictions like other asylum groups. ${ }^{17}$ In the end, the RTP gave rise to an ambiguous legal category that can be terminated by at the discretion of policy makers.

Unlike previous periods, the government response to Syrian refugee reception was politicized by opposition political parties, yet the articles suggests the governance of forced migration in post-2015 period carried the legacy of the earlier technocratic approach. Refugees on the route to European countries as a spill over effect of the Syrian conflict reinforced migration diplomacy between Turkey and the EU despite the fact that Turkey's prospects for EU membership have long since faded away. The EUTurkey Joint Action Plan enacted in November 2015 and the EU-Turkey statement on additional action points of March 2016 were an outcome of the EU governments' panic due to the increasing number of migrants and refugees arriving in Europe during the summer of 2015 and media attention on 'border spectacles' along the Aegean shores. The mobility of refugees and migrants from Syria and other source countries transiting through Turkey towards Europe in summer 2015 has consolidated migration as a diplomatic bargaining tool within ongoing migration diplomacy between Turkey and the

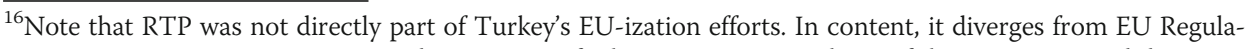
tion on Temporary Protection as it does not specify the maximum time limit of the protection and does not provide access to RSD procedures upon termination (Ineli-Ciger, 2015 p.31-32).

${ }^{17}$ Syrians in Turkey, as well as other asylum-seeking groups, are eligible to benefit from rights and services only in the province where they are registered with the authorities.
} 
EU (İçduygu \& Üstübici, 2014). In this context, along with earlier instruments of externalization, the statement illustrates different aspects of the production of differentiated legal status within the interplay between control and humanitarian intervention.

The Turkey-EU statement of March 2016 had three important components. The first involved the return of all new irregular migrants crossing from Turkey to the Greek islands as of 20 March 2016. Second, the statement declared the intent to resettle one Syrian from Turkey to the EU for every Syrian returned to Turkey from the Greek islands. Third, financial aid was channelled to Turkey to improve the living conditions of refugees. In return, Turkey was promised a re-energizing of membership negotiations and the continuation of negotiations on visa liberalization for Turkish nationals travelling to EU countries. In line with the discussion on the Readmission Agreement of 2013, the statement was presented in the media as a 'technical commitment', a political requirement that would ensure the continuation of successful negotiations between the EU and Turkey. In this sense, the technocratic character of the policy discussion continued to mark the governance of international mobility in Turkey as of early 2016 and to overshadow its socio-legal implications, despite an unprecedentedly high number of newly arrived refugees and increasing resentment towards Syrians (ICG, 2018).

Experts in the EU and Mediterranean have evaluated the forced return of migrants from the Greek islands as the most problematic aspect of the March 2016 statement and EU financial support to be channelled for the integration of refugees as the least problematic aspect (Üstübici, 2017). While the deal arguably gave the upper hand to Turkey in the ongoing migration diplomacy (Ataç et al., 2017) and consolidated the role of migration as a bargaining tool in Turkey-EU relations, the ways in which it brought pertinent aspects of externalization re-constructing migrant illegality into the picture should be highlighted. In other words, the statement not only provides evidence for the continuation of externalization dynamics filtering among migrant groups and thus contributing to the international production of migrant illegality, it exemplifies the interplay between the dynamics of control and humanitarian intervention in the governance of migration.

With the Turkey-EU agreement in March 2016, Turkish authorities have increased land and sea patrols within the humanitarian discourse of saving lives, as was made clear in the Commission's report: 'The short-term objectives of the framework are to "save lives in the Mediterranean Sea; increase the rate of returns to countries of origin and transit"; and "enable migrants and refugees to stay close to home and to avoid taking dangerous journeys" (Frelick et al., 2016, p. 208). Intending to filter Syrians from non-Syrians, the implementation of the deal reinforces the international production of migrant illegality. By law, Syrians who cross the border are no longer under temporary protection, but an exception is made for Syrians readmitted from the Greek islands in the context of the Turkey-EU deal. In practice, however, there is evidence that for Syrians who are returned from the Greek islands, re-registering under the RTP is not always possible. Furthermore, the majority of people apprehended at the Turkey-Greece border are from other countries, such as Afghanistan, Pakistan, Iran and Iraq but also Algeria, Morocco and Tunisia. Reports reveal that they have been detained and deported by Turkish authorities (Ulusoy \& Battjes, 2017).

The strengthening of the securitized approach envisaged by the deal can be extended to other developments in the aftermath of March 2016 whereby the control aspects of externalization have become much more visible. The Turkish government constructed 
walls along the Turkish side of the border with Syria and another is under construction along the Turkey-Iran border. Such measures reveal the contagious impact of border externalization (Üstübici \& Içduygu, 2018). In addition, under the state of emergency in Turkey declared in July 2016 in the aftermath of a failed coup attempt, Decree Law No. 676 expanded the scope of deportations, facilitating the refoulement of people under international protection and RPT under the auspices of national security and restricting the right to appeal (Sarı \& Dinçer, 2017, pp. 77-78). Although Syrians under temporary protection are also subject to deportation under the decree, the haphazard forced return of thousands of Afghan nationals crossing the Turkey-Iran border in large numbers in mid-2018, in addition to detention in urban centres and deportation, reveals the differentiated treatment of various groups with potential asylum claims (Zaman, 2018).

The financial support channelled to Turkey for improving the situation of Syrian refugees has been the least problematized part of the deal by experts in the field (Üstübici, 2017). Even within the context of humanitarian intervention, however, a direct outcome of externalization has been the reinforcement of legal hierarchies with interrelated aims of controlling certain groups. The biggest portion of financial support went to cash transfers, a joint venture by the World Food programme, the Turkish Red Crescent and the Turkish government. The programme introduced cash transfer through banks for family members of non-camp refugees in Turkey. The selection of families benefiting from cash transfers highlights again differentiation among the communities seeking protection based on legal status and degrees of vulnerability (Sözer, 2019). As reported by the European Commission, with a 1 billion euro budget, 1.3 million Syrians in Turkey are benefiting from the Red Crescent Card as of April 2018, funded by the Emergency Social Safety Net. Beneficiaries have an average household size of 5.8 people.

Despite the legal privileges that distinguish one category from another, these categories create a lot of uncertainties for individuals subjected to them. Even Temporary Protection, which on paper enables Syrians to enjoy access to rights and services that other refugee groups cannot, is far from providing a long term solution towards settlement and integration. As part of the measures regarding integration, the Regulation on Work Permit of Refugees under Temporary Protection was introduced in January 2016, part of the agenda from the EU-Turkey Joint Action Plan of November 2015. The regulation has enabled easier access to work permit procedures for Syrians under TP. This scheme was later adopted for other groups who are conditional refugees under the law. By March 2018, reportedly only 20,000 work permits had been issued for Syrians under TP in Turkey. ${ }^{18}$ Putting this figure in perspective, there are over 2 million Syrians of working age under temporary protection in Turkey; this reveals the limitations of integration measures. The regulation introduces a maximum $10 \%$ quota for the employment of Syrians in most sectors. In practice, the work permit regulation prioritizes those with financial and cultural capital, such as business owners, young refugees with linguistic skills or those with connections employed by the non-profit sector, leaving most Syrians and other groups seeking international protection in the hands of a highly informal and abusive labour market. ${ }^{19}$

\footnotetext{
${ }^{18}$ The media has reported that as of March 2018, there were a total of 39,935 Syrians granted work permits in Turkey. Based on data provided by the Ministry of Labour and Social Security, around half of them $(19,578)$ are under TP while the rest have regular residence permits to reside in Turkey. Out of the total number, 13,327 Syrians have their own business.
} 
Nevertheless, one may say that Syrians under RTP are near the top of the legal hierarchy amongst asylum-seeking communities in terms of accessing services and benefits, despite their exclusion from the RSD process and discretionary nature of their status. However, given the discrepancy between law and practice, their experiences in the labour market and social life are quite similar to other refugee and migrant groups. Indeed, in the treatment of Syrians under the RTP in Turkey, one may clearly observe how humanitarian and control regimes operate together and how such operations are not limited to direct measures of border externalization. The spirit of these laws and the mechanisms of their implementation are inspired or influenced by technocratic and external migration governance. Hence, the analytical approaches to recent interventions should draw parallels to early forms of migration governance, inscribed in the external and technical approach. At the same time, there is room to recognize the continuation of the interplay between control and humanitarian intervention, seen as a significant component of border externalization.

\section{Concluding remarks}

The externalization of border and migration policies has become the central policy framework for the governance of international migration for the European Union, with implications for its wider region, especially for countries such as Turkey. Dealing with socio-legal implications, this article has discussed that the emergence of differentiated legal status amongst migrants and refugee groups have been one outcome of externalization measures in Turkey and that this process was embedded within a technocratic approach to migration governance despite recent politicization. The article has demonstrated that the symptoms of "multi-layered governance regime" or "differentiated inclusion" as raised by recent scholarship on Turkey were already there before the Syrian refugee situation erupted. The conceptual part has laid out that emerging (multi-layered) migration governance in Turkey need to contextualized and conceptualized as an extension of control and humanitarian dynamics of border externalization that had already started in early 2000s. The empirical parts provided an overview of migration governance in Turkey highlighting the changes and continuation in dynamics of governance over three distinct periods of externalization since the early 1990s. The empirical analysis has provided evidence that certain aspects of externalization in terms of migration governance have been procedurally internalized without too much attention to their socio-legal implications.

Migration governance in Turkey has initially been underpinned by the increasing involvement of the $\mathrm{EU}$ in the border infrastructure and, later, the legal infrastructure of 'transit countries', as well as the increasing activities of international/ intergovernmental organizations such as the UNHCR and IOM. The new legislation and institutions since 2008 marked the shift from no policy to a policy on immigration and asylum or from discretion to technocratic approaches to migration governance. They also gave rise to emergence of more rigid categories than before, such as legal migration, irregular migration, international protection and subsidiary protection as distinguished in LFIP, marking the internalization of the filtering aspects of externalization dynamics.

\footnotetext{
${ }^{19}$ The Turkish government has invited a number of Syrians to apply for citizenship, especially skilled and educated individuals. The outcomes of this policy have yet to be researched and discussed but it clearly reveals another equally contradictory form of filtering in naturalization practices.
} 
Curiously enough, in the case of Turkey these developments have occurred in an environment where refugee and migration issues have not been part of an informed political discussion. This trend has recently changed, as authorities have realized that Syrians under TP are likely to stay for a longer term than initially envisaged. As a consequence, since 2012, there has been an overwhelming focus on Syrian refugees at the level of policy and humanitarian intervention without much discussion on other groups. The article acknowledges that response to Syrian refugee reception has led to the politicization of migration governance at a greater degree than earlier periods. At the same time, it also has the legacy of the earlier technocratic approach especially after 2015. Therefore, there is still empirical ground to discuss the socio-legal impact of externalization.

Responses to the Syrian refugee issue in Turkey display continuities in governance from previous periods, such as the external and technical character of policy making, seeing migration policies as part of relations with the EU and making migration governance a more explicit bargaining tool. Accordingly, the external and technical character of pre-existing practices of migration management had an impact on the relatively lower level of politicization of international migration in Turkey at the onset, shaping the production of differentiated legal statuses that has become much more obvious in the aftermath of the Syrian crisis. Externalization coupled with Turkey's multi-layered governance have had a filtering effect; where all groups are controlled, some are made subject to humanitarian intervention. Additionally, the treatment of Syrian refugees in Turkey has been characterised by the logics of control and humanitarianism. This process has arguably been reinforced with the implementation of the Turkey-EU statement of March 2016.

It is clear that externalization is now the main plank of EU migration policy (Frelick et al., 2016, p. 208), if not of the global approach to migration governance. Despite the already controversial outcomes of the Turkey-EU deal, migration diplomacy between Turkey and the EU is likely to stay on the agenda regardless of the future of EU accession talks. The impacts of externalization leading to different forms of migration diplomacy is yet to be theorized and Turkey provides a very rich empirical case to further explore migration governance between external and internal dynamics.

Regulatory measures similar to European externalization are already in place in North American and South East Asia. These externalization policies have the potential to reinforce differentiation amongst migrant communities in third countries, disguising complexities involved in these differentiations, as they are built on technocratic frames. Further research may explore to extent to which humanitarian discourse is subordinated to a control discourse in various contexts, taking into account the potential impact of externalization on historical patterns of 'South-South' mobility.

\section{Abbreviations}

CSO: Civil society organization; DGMM: Directorate General of Migration Management; ECtHR: European Court of Human Rights; EU: European Union; IOM: International Organization for Migration; LFIP: Law on Foreigners and International Protection; Mol: Ministry of the Interior; RA: Readmission Agreement; RSD: Refugee status determination; RTP: Regulation on Temporary Protection; TP: Temporary Protection; UNHCR: United Nations High Commission for Refugees 
grateful for the IPC Mercator Fellowship programme at SWP Berlin for providing the physical environment for the writing of this article.

\section{Authors' contributions}

This study was designed and directed by the author as part of her PhD Thesis and followed by further research on the developments of migration governance in Turkey in the post-2014 period. The author conducted the interviews, analysed the data and wrote the manuscript. The author read and approved the final manuscript.

\section{Funding}

The author is grateful to the KOCKAM (Koç University Center for Gender Studies) and Bucerius Settling into Motion Scholarship Program for financing the fieldwork in Turkey between 2012 and 2014. The author is also grateful for IPC Mercator Fellowship programme at SWP Berlin for creating the physical environment for the writing of this article.

\section{Availability of data and materials}

The dataset including qualitative interviews and fieldwork notes supporting the results of this article are not publicly available due to data protection issues.

\section{Ethics approval and consent to participate}

The research is approved by Koc University Ethics Committee.

\section{Consent for publication}

Not applicable.

\section{Competing interests}

The author declares that she has no competing interests.

Received: 22 August 2018 Accepted: 9 October 2019

Published online: 11 December 2019

\section{References}

Aras, N. E. G., \& Mencütek, Z. Ş. (2018). Evaluation of irregular migration governance in Turkey from a foreign policy perspective. New Perspectives on Turkey, 59, 63-88.

Ataç, I., Heck, G., Hess, S., Kaşlı, Z., Ratfisch, P., Soykan, C., \& Y.lmaz, B. (2017). Contested B/Orders. Turkey's changing migration regime. An introduction. movements. Journal for Critical Migration and Border Regime Studies, 3(2), 9-21.

Baban, F., Ilcan, S., \& Rygiel, K. (2017). Syrian refugees in Turkey: Pathways to precarity, differential inclusion, and negotiated citizenship rights. Journal of Ethnic and Migration Studies, 43(1), 41-57.

Biehl, K. S. (2015). Governing through uncertainty: Experiences of being a refugee in Turkey as a country for temporary asylum. Social Analysis, 59(1), 57-75.

Bigo, D. (2014). The (in)securitization practices of the three universes of EU border control: Military/Navy - border guards/ police - database analysts. Security Dialogue, 45(3), 209-225. https://doi.org/10.1177/0967010614530459.

Boswell, C. (2003). The 'external dimension' of EU immigration and asylum policy. International Affairs, 79(3), 619-638. https:// doi.org/10.1111/1468-2346.00326.

Brouillette, M. (2018). From discourse to practice: The circulation of norms, ideas and practices of migration management through the implementation of the mobility partnerships in Moldova and Georgia. Comparative Migration Studies, 6. https://doi.org/10.1186/s40878-017-0066-y

Casas-Cortes, M., Cobarrubias, S., \& Pickles, J. (2016). 'Good neighbours make good fences': Seahorse operations, border externalization and extra-territoriality. European Urban and Regional Studies, 23(3), 231-251.

Danış, D., \& Parla, A. (2009). Nafile soydaşlı: Irak ve Bulgaristan Türkleri örneğinde göçmen, dernek ve devlet [Ethnic kinship in vain: migrant, association and state in the case of Turks from Iraq and Bulgaria]. Toplum ve Bilim, 114, 131-158.

Dardağan Kibar, E. (2013). An overview and discussion of the new Turkish law on foreigners and international protection. Perceptions, 18(3), 109-128.

De Genova, N. (2004). The legal production of Mexican/Migrant "illegality". Latino Studies, 2(2), 160-185.

De Genova, N. (2015). Extremities and regularities: Regulatory regimes and the spectacle of immigration enforcement. In Y. Jansen, R. Celikates, \& J. De Bloois (Eds.), The Irregularization of migration in contemporary Europe, (pp. 3-14). London Newyork: Rowman \& Littlefield.

European Commission (2013, December 16). Cecilia Malmström signs the Readmission Agreement and launches the Visa Liberalisation Dialogue with Turkey. [Press Release]. Retrieved from https://europa.eu/rapid/press-release_IP-13-1259_ en.htm

Fine, S. (2018). Liaisons, labelling and laws: International organization for migration bordercratic interventions in Turkey. Journal of Ethnic and Migration Studies, 44(10), 1743-1755.

Frelick, B., Kysel, I. M., \& Podkul, J. (2016). The Impact of Externalization of Migration Controls on the Rights of Asylum Seekers and Other Migrants. Journal on Migration \& Human Security, 4(4), 190-220. Retrieved from https://journals.sagepub.com/ doi/pdf/10.1177/233150241600400402.

Garcés-Mascareñas, B. (2012). Labour migration in Malaysia and Spain: Markets, citizenship and rights. Amsterdam: Amsterdam University Press.

Geiger, M., \& Pécoud, A. (2010). The politics of international migration management. In: Geiger, M., \& Pécoud, A. (Eds.) The politics of international migration management (pp. 1-20). London: Palgrave Macmillan.

Genç, F., Heck, G., \& Hess, S. (2019). The multilayered migration regime in Turkey: contested regionalization, deceleration and legal precarization. Journal of Borderlands Studies, 34(4), 489-508.

Grange, M., \& Flynn, M. (2014). Immigration Detention in Turkey. Retrieved from https://www.globaldetentionproject.org/wpcontent/uploads/2016/06/Turkey_report.pdf. 
HCA (2007). Unwelcome guests: The detention of refugees in Turkey's "foreigners' guesthouses". İstanbul: Helsinki Citizens Assembly Refugee Advocacy \& Support Program.

Huysmans, J. (2006). The politics of insecurity: Fear, migration and asylum in the EU. London and New York: Routledge.

Içduygu, A. (2007). EU-ization matters: Changes in immigration and asylum practices in Turkey. In T. Faist, \& A. Ette (Eds.), The Europeanization of national policies and polities of immigration, (pp. 201-222). London: Palgrave MacMillan Publishers.

Içduygu, A., \& Aksel, D.B. (2012). Irregular migration in Turkey. Ankara: International Organization for Migration. Retrieved https://www.academia.edu/6151302//rregular_Migration_in_Turkey_co-authored_with_Ahmet_lcduygu_.

İçduygu, A., \& Üstübici, A. (2014). Negotiating mobility, debating borders: Migration diplomacy in Turkey-EU relations. In H. Schwenken, \& S. Ruß-Sattar (Eds.), New border and citizenship politics, (pp. 44-59). London: Palgrave Macmillan

International Crisis Group (2018). Turkey's Syrian refugees: Defusing Metropolitan Tensions (Report No. 248). Brussels: International Crisis Group. Retrieved from https://www.crisisgroup.org/europe-central-asia/western-europemediterranean/ turkey/248-turkeys-syrian-refugees-defusing-metropolitan-tensions.

Ineli-Ciger, M. (2015). Implications of the new Turkish law on foreigners and international protection and regulation no. 29153 on temporary protection for Syrians seeking protection in Turkey. Oxford Monitor of Forced Migration, $4(2), 28-36$.

Işleyen, B. (2018a). Transit mobility governance in Turkey. Political Geography, 62, 23-32. https://doi.org/10.1016/j. polgeo.2017.09.017.

Işleyen, B. (2018b). Turkey's governance of irregular migration at European Union borders: Emerging geographies of care and control. Environment and Planning D: Society and Space, 36(5), 849-866. https://doi.org/10.1177/0263775818762132.

Karadağ, S. (2019). Extraterritoriality of European borders to Turkey: An implementation perspective of counteractive strategies. Comparative Migration Studies, 7. https://doi.org/10.1186/s40878-019-0113-y.

Kıııç, T. (2014). Batı Sınııından Doğu Sınııına: Geri Kabul Anlaşması, "Push Back" ve Özbek Mülteciler [From Western to Eastern borders: Readmission Agreement, "Push Back"and refugees from Uzbekistan]. In D. Danış, \& I. Soysüren (Eds.), Sinır ve Sinırdışs: Türkiye'de Yabancılar, Göç ve Devlete Disiplinlerarası Bakışlar [Border and Deportation: Interdisiplinary perspectives on foreigners, migration and state in Turkey], (pp. 427-449). İstanbul: Notabene.

Kirişci, K. (2012). Turkey's new draft law on asylum: What to make of it? In: S. P. Elitok, \& T. Straubhaar (Eds.), Turkey, migration and the EU: Potentials, challenges and opportunities, (pp. 63-84). Hamburg: Hamburg University Press.

Korkut, U. (2016). Pragmatism, moral responsibility or policy change: The Syrian refugee crisis and selective humanitarianism in the Turkish refugee regime. Comparative Migration Studies, 4. https://doi.org/10.1186/s40878-015-0020-9.

Lavenex, S., \& Schimmelfennig, F. (2009). EU rules beyond EU borders: Theorizing external governance in European politics. Journal of European Public Policy, 16(6), 791-812.

Lavenex, S., \& Uçarer, E. M. (2004). The external dimension of Europeanization: The case of immigration policies. Cooperation and Conflict: Journal of the Nordic International Studies Association, 39(4), 417-443.

Menjívar, C. (2014). Immigration law beyond borders: Externalizing and internalizing border controls in an era of securitization. Annual Review of Law and Social Science, 10, 353-369.

Oelgemöller, C. (2011). 'Transit'and 'suspension': Migration management or the metamorphosis of asylum-seekers into 'illegal' immigrants. Journal of Ethnic and Migration Studies, 37(3), 407-424.

Ozcurumez, S., \& Şenses, N. (2011). Europeanization and Turkey: Studying irregular migration policy. Journal of Balkan and Near Eastern Studies, 13(2), 233-248.

Özgür, N., \& Özer, Y. (2010). Türkiye'de sığınma sisteminin Avrupallıaştrılması [Europeanization of asylum system in Turkey]. Istanbul: Derin Yayınları.

Pallister-Wilkins, P. (2015). The humanitarian politics of European border policing: Frontex and border police in Evros. International Political Sociology, 9(1), 53-69.

Qadim, N. E. (2014). Postcolonial challenges to migration control: French-Moroccan cooperation practices on forced returns. Security Dialogue, 45(3), 242-261.

Sarı, E., \& Dinçer, C. G. (2017). Toward a new asylum regime in Turkey? MOVEMENTS Journal for Critical Migration and Border Regime Studies, 3(2), 59-79. Retrieved from https://movements-journal.org/issues/05.turkey/05.sari,dincer--new-asylumregime-turkey.html.

Soykan, C. (2017). Turkey as Europe's gatekeeper. In S. Hess, B. Kasparek, S. Kron, M. Rodatz, M. Schwertl, \& S. Sontowski (Eds.), Recent developments in the field of migration and asylum and the EU-Turkey deal, (pp. 52-60). Berlin Hamburg: Assosiation A.

Sözer, H. (2019). Categories that blind us, categories that bind them: The deployment of vulnerability notion for Syrian refugees in Turkey. Journal of Refugee Studies. Advance online publication. https://doi.org/10.1093/jrs/fez020.

Toksöz, G., Erdoğdu, S., \& Kaşka, S. (2012). Irregular migration in Turkey and the situation of migrant workers in the labour market. Ankara: IOM.

Tolay, J. (2012). Turkey's "critical Europeanization": Evidence from Turkey's immigration policies. In S. P. Elitok, \& T. Straubhaar (Eds.), Turkey, migration and the EU: Potentials, challenges and opportunities, (pp. 39-62). Hamburg: Hamburg University Press.

Tsianos, V., \& Karakayali, S. (2010). Transnational migration and the emergence of the European border regime: An ethnographic analysis. European Journal of Social Theory, 13(3), 373-387. https://doi.org/10.1177/1368431010371761.

Ulusoy, O., \& Battjes, H. (2017). Situation of readmitted migrants and refugees from Greece to Turkey under the EU-Turkey statement. VU Migration Law Series No, 15, 1-42.

Üstübici, A. (2017). EU-Turkey cooperation on migration (Euromed survey, 7th ed.). Survey of Experts and Actors on the EuroMediterranean Region. Retrieved from https://www.iemed.org/publicacions/historic-de-publicacions/enquesta-euromed/ euromed-survey-2016/contents.

Üstübici, A. (2018). The governance of international migration: Irregular migrants' access to right to stay in Turkey and Morocco. Amsterdam: Amsterdam University Press.

Üstübici, A., \& içcuyggu, A. (2018). Border closures and the externalization of immigration controls in the Mediterranean: A comparative analysis of Morocco and Turkey. New Perspectives on Turkey, 59, 7-31.

Wunderlich, D. (2013). Towards coherence of EU external migration policy? Implementing a complex policy. International Migration, 51(6), 26-40. 
Yıldız, U., \& Sert, D. (2017). Göçün jeopolitiği ve Türkiye'nin coğrafi kıııtlaması üzerine farkı bir yorum [Geopolitics of migration and a different interpretation on Turkey's geographical limitation]. Toplum ve Bilim, 140, 93-106.

YIImaz, G. (2012). The impact of foreign nationals on state policy: Refugees and asylum seekers, European court of human rights case law and Turkish asylum law. (Unpublished master's thesis). Istanbul Boğaziçi University.

Zaman, A. (2018, April 24). Afghans fleeing violence unwelcome in Turkey. Al-Monitor. Retrieved from https://www.al-monitor. com/pulse/originals/2018/04/turkey-snap-vote-refugees.html.

\section{Publisher's Note}

Springer Nature remains neutral with regard to jurisdictional claims in published maps and institutional affiliations.

Submit your manuscript to a SpringerOpen ${ }^{\odot}$ journal and benefit from:

- Convenient online submission

- Rigorous peer review

- Open access: articles freely available online

- High visibility within the field

- Retaining the copyright to your article

Submit your next manuscript at $\boldsymbol{\nabla}$ springeropen.com 